\title{
Freshwater influx, hydrographic reorganization and the dispersal of ice-rafted detritus in the sub-polar North Atlantic Ocean during the last deglaciation
}

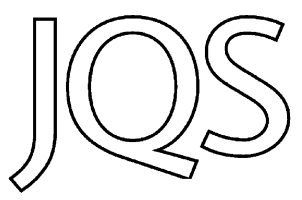

\author{
DAVID SMALL, ${ }^{*} \dagger$ WILLIAM AUSTIN and VINCENT RINTERKNECHT \\ School of Geography Geosciences, University of St Andrews, St Andrews, Scotland
}

Received 6 March 2013; Revised 24 April 2013; Accepted 26 April 2013

\begin{abstract}
A sediment core from the north-east North Atlantic contains high-resolution co-registered foraminiferal $\delta^{18} \mathrm{O}$ and ice-rafted detritus (IRD) records for the last deglaciation. These reveal a distinct ice-rafting event that occurred at the time of Greenland Interstade 1d (GI-1d), a feature also seen in other high-resolution cores from the North Atlantic. The occurrence of a geographically widespread peak in IRD at ice distal sites at a time when increased freshwater flux to the surface ocean is inferred to have caused rapid cooling suggests a mechanistic link between the processes, analogous to the Younger Dryas (GS-1) cooling episode. The general absence of IRD at southern locations at other times during GI-1 when the flux of icebergs from surviving ice sheets to northern locations continued suggests that the Gl-1d IRD peak represents a time of hyrdrographic reorganization which changed IRD dispersal. While numerous studies have suggested freshwater flux as a major driver of rapid climate oscillations observed around the North Atlantic during the last deglaciation, the evidence presented here both supports that mechanism and highlights the potential for rapid and major reorganization of the North Atlantic's surface hydrography to explain changes in IRD flux independently of ice sheet calving dynamics.

Copyright (C) 2013 John Wiley \& Sons, Ltd.
\end{abstract}

KEYWORDS: deglaciation; hydrography; ice-rafted detritus; North Atlantic; sea surface temperature.

\section{Introduction}

High-resolution records spanning the Lastglacial-Interglacial Transition (LGIT) have consistently revealed a climate system punctuated by numerous abrupt climate transitions (Severinghaus and Brook, 1999; Alley et al., 2003; Steffensen et al., 2008). Several of these events have been linked to changes in Atlantic Meridional Overturning Circulation (AMOC) and its associated heat flux because of its sensitivity to increased freshwater input (Clark et al., 2001, 2002; McManus et al., 2004). To firmly establish freshwater forcing as an underlying causal mechanism of these abrupt climate transitions requires, firstly, well-constrained chronostratigraphies such that events can be correlated between records with confidence and, secondly, widespread geological evidence that links the North Atlantic's surface conditions to changes in the deep and intermediate ocean.

The occurrence of ice-rafted detritus (IRD) within marine sediments has long been used to investigate the links between climate, oceans and ice sheets (Heinrich, 1988; Bond et al., 1993; Elliot et al., 2001; Knutz et al., 2001; Hemming, 2004; Peck et al., 2007; Hendy and Cosma, 2008; Scourse et al., 2009). To fully understand these links, it is not only important to understand how variations in IRD relate to ice sheet advance and/or retreat (McCabe and Clark, 1998; Marshall and Koutnik, 2006) but also to develop an understanding of the way hydrographic controls can influence the dispersal of IRD within an oceanic basin. There has been relatively little work relating hydrographic factors to IRD records, although some authors have argued for minimal hydrographic control in parts of the sub-polar North Atlantic (Elliot et al., 2001) and in relation to the first occurrences of Heinrich-like events in the earlier Pleistocene (Naafs et al., 2011). One situation where hydrographic controls have

${ }^{*}$ Correspondence: D. Small, at ${ }^{\dagger}$ present address below.

E-mail: david.small@glasgow.ac.uk

†Present address: School of Geographical and Earth Sciences, University of Glasgow, Glasgow G12 8QQ, Scotland. been cited as influencing the pattern of IRD deposition is in regards to the location of the IRD Belt (Fig. 1) (Ruddiman, 1977; Ruddiman and McIntyre, 1981; Scourse et al., 2009).

Potential hydrographic controls include the pattern of oceanic surface currents which affect the dispersal of icebergs and thus IRD and, potentially more importantly, sea surface temperature (SST). Palaeoclimatic records indicate that large and abrupt changes to AMOC during the last glacial period were associated with changes in climate (Vidal et al., 1997; Austin and Kroon, 2001; Clark et al., 2002; Rahmstorf, 2002; McManus et al., 2004; Thornalley et al., 2010). Freshwater input to the North Atlantic is suggested to be one of the major drivers of changes to AMOC and attendant climatic impacts (Broecker, 1994). This link is supported by proxy data (Elliot et al., 2002; McManus et al., 2004) and modelling studies (LeGrande et al., 2006; Clarke et al., 2009; Liu et al., 2009; He et al., 2013), which demonstrate that a weakening of AMOC is associated with cooling and lower SSTs. SSTs influence the melt rates of icebergs and hence their longevity in the open ocean; as such, icebergs are more likely to travel large distances across ocean basins during times of lower SSTs. IRD peaks in ice distal sites at these times may reflect the increased persistence and dispersal of icebergs, relating to hydrographic conditions, rather than an increased total flux of icebergs related to ice sheet dynamics. Comparing IRD records from distal sites with records relating to temporal variations in iceberg flux (both proximal and distal) can allow these links to be investigated.

High-resolution records spanning the LGIT are punctuated by numerous IRD events which some authors have linked directly to changes in ice sheet dynamics (e.g. Knutz et al., 2001); given the potential influence of SST variations highlighted above it is imperative to establish if making such inferences is valid. Such an understanding will aid attempts to integrate records of oceanic changes with ice sheet behaviour and explore the two-way forcing relationship that exists (Clark et al., 2001). Here we present a new, highresolution IRD record from the north-east North Atlantic and 


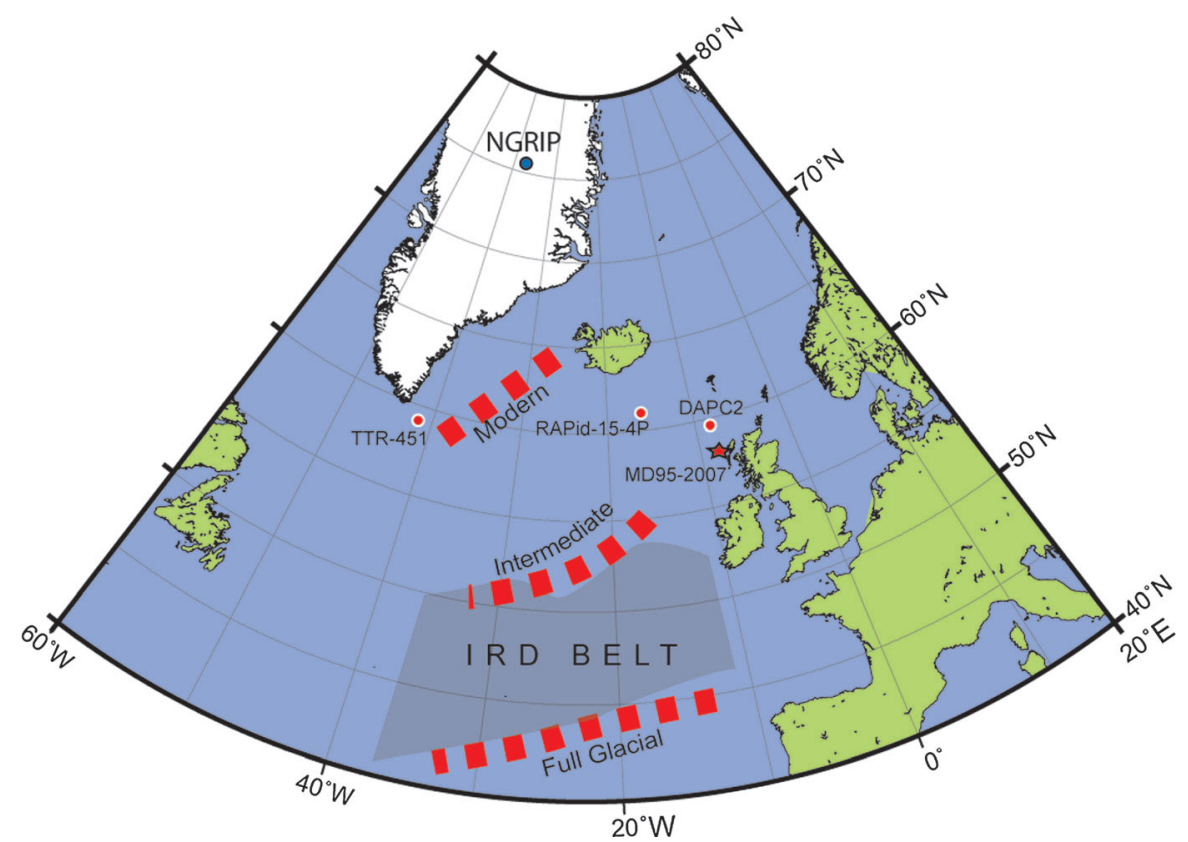

Figure 1. Map of the North Atlantic showing the location of MD95-2007 (red star) and other cores mentioned in the text. Also shown is the IRD belt of Ruddiman (1977) and the approximate location of the polar front (dashed red line) at various times in the past after McManus et al. (1994). This figure is available in colour online at wileyonlinelibrary.com.

use it to identify a distinct and widespread LGIT ice rafting event. Its timing, as indicated by a major change in the coregistered foraminiferal $\delta^{18} \mathrm{O}$, coincides with the cold interval of Greenland Interstade 1d (Gl-1d; Lowe et al., 2008). Episodic freshwater input to the North Atlantic has been proposed as the cause of such cold intervals that punctuate the LGIT (Thornalley et al., 2010). Establishing the effects of such input has important implications for our understanding of rapid climate change during the last deglaciation as it provides a linking mechanism between ice sheets and changes in oceanic circulation.

\section{Study site and methods}

\section{Study site}

Giant Piston Core MD95-2007 was collected in 1995 from the $R V$ Marion Dufresne in the St Kilda basin on the Hebridean shelf, north-west Scotland $\left(57^{\circ} 31.057^{\prime} \mathrm{N}, 08^{\circ}\right.$ $23.171^{\prime} \mathrm{W}, 158 \mathrm{~m}$ water depth, $19.35 \mathrm{~m}$ recovery; Fig. 1 ). The St Kilda basin is a glacially over-deepened basin that is within the limits of the last British-Irish Ice Sheet (BIIS) (Davies et al., 1984; Peacock et al., 1992; Stoker et al., 1993). This conclusion is supported by a ${ }^{14} \mathrm{C}$ date of $22480 \pm 300{ }^{14} \mathrm{C}$ a BP [27.1 cal ka BP (OxCal v4.1, Bronk Ramsey, 2009), MARINE09 (Reimer et al., 2009)] on marine shell material to the west of morainal banks marking the aforementioned BIIS limit and of 'basal' ages $<16{ }^{14} \mathrm{C}$ ka BP $(<19$ cal ka BP $)$ within those same limits (Peacock et al., 1992; Austin and Kroon, 1996). These ages demonstrate that this sector of the BIIS was at its maximum extent before $20 \mathrm{ka}$. As MD95-2007 is located within these ice limits it is thought to record nearly the entire deglacial sequence following initial deglaciation of the shelf edge.

The potential for cores recovered from the St Kilda basin to record high-resolution records of the LGIT was initially demonstrated from two vibrocores VE57/-09/89 and VE57/09/46 (Austin, 1991; Peacock et al., 1992; Austin and Kroon, 1996). These cores showed an expanded LGIT sedimentary sequence but a poorly resolved Holocene sequence. From the variety of sedimentary, micropalaeonto- logical and isotopic evidence recorded in these cores it was proposed that the St Kilda basin deglaciated at $15.2{ }^{14} \mathrm{C}$ ka BP (17.6 cal ka BP) after which its waters remained cold with low salinity until $13.5{ }^{14} \mathrm{C}$ ka BP (15.6 cal ka BP). Following this time, mostly warm interstadial conditions prevailed until a major cooling associated with the onset of GS-1 was observed at $11.6{ }^{14} \mathrm{C}$ ka BP $(13.0 \mathrm{cal} \mathrm{ka} \mathrm{BP})$. The return to higher temperatures at the beginning of the Holocene occurred before $10{ }^{14} \mathrm{C}$ ka BP (11 cal ka BP) (Austin and Kroon, 1996).

\section{A revised chronostratigraphy for MD95-2007}

The original age model for MD95-2007 (Wilson, 2004) was based on 16 accelerator mass spectrometry (AMS) ${ }^{14} \mathrm{C}$ ages (Table 1) calibrated using Calib4_2 (Stuiver and Reimer, 1993; Stuiver et al., 1998), following a reservoir correction $\left(R_{(\mathrm{t})}\right)$ reflecting the modern values of seawater (i.e. $\triangle R=0$ ). The availability of a $\delta^{18} \mathrm{O}$ record $\left(\delta^{18} \mathrm{O}_{\text {foram }}\right)$, measured in the epi-benthic foraminifera Cibicides lobatulus (originally reported in Austin et al., 2011), provides an additional means of improving the age-depth relationship. The new age model for MD95-2007 is shown in Fig. 2. Given the rapid and abrupt nature of the Gl-1 climate oscillations, the high resolution of the MD95-2007 $\delta{ }^{18} \mathrm{O}_{\text {foram }}$ record and inherent uncertainty about the variable marine reservoir effect during this period (Austin et al., 1995, 2011), it is important to determine the timing of particular climatic episodes during GI-1 vis-à-vis the candidate cold episodes Gl-1d or Gl-1b (see Fig. 3). This is done by constraining the $\delta^{18} \mathrm{O}_{\text {foram }}$ record using recalibrated $\mathrm{AMC}{ }^{14} \mathrm{C}$ ages [OxCal v4.1, MARINE09 (Bronk Ramsey, 2009; Reimer et al., 2009)] with three different values for $R_{(\mathrm{t})}$ : the modern value 400 years $(\triangle R=0)$, the commonly cited GS- 1 value 700 years $(\triangle R=300)$ and a maximum value of 1100 years $(\triangle R=700)$ (Waelbroeck et al., 2001). This approach provides a good first-order constraint to the age of the interstadial $\delta^{18} \mathrm{O}_{\text {foram }}$ excursion (Austin et al., 2011). In order for this excursion to correlate with Gl-1b (13 300-13 $100 \mathrm{~b} 2 \mathrm{k}$ ) the reservoir age correction would need to exceed 1000 years (Fig. 3). A reconstruction of $R_{(\mathrm{t})}$ at this time from MD95-2007 indicates that it was lower 
Table 1. ${ }^{14} \mathrm{C}$ Ages from MD95-2007.

\begin{tabular}{|c|c|c|c|c|c|c|}
\hline \multirow[b]{2}{*}{ Sample } & \multirow[b]{2}{*}{$\begin{array}{l}\text { Core depth } \\
\quad(\mathrm{cm})\end{array}$} & \multirow[b]{2}{*}{$\begin{array}{c}\text { Radiocarbon age } \\
\left({ }^{14} \mathrm{C} \text { a } \mathrm{BP} \pm 1 \text { sigma }\right)\end{array}$} & \multicolumn{4}{|c|}{ Calibrated age (cal a BP) } \\
\hline & & & $\triangle R=0$ & $\triangle R=300$ & $\triangle R=700$ & Original age* \\
\hline AA-41753 & 21 & $2279 \pm 36$ & $2285 \pm 62$ & $1537 \pm 56$ & $1140 \pm 51$ & 1879 \\
\hline AA-41754 & 121 & $10664 \pm 65$ & $12601 \pm 61$ & $11394 \pm 143$ & $10926 \pm 121$ & $11825+$ \\
\hline AA-41762 & 375.5 & $11353 \pm 62$ & $13231 \pm 65$ & $12583 \pm 81$ & $11987 \pm 137$ & 12907 \\
\hline AA-41755 & 396.5 & $11299 \pm 66$ & $13195 \pm 72$ & $12512 \pm 88$ & $11873 \pm 158$ & 12890 \\
\hline AAR-2602 & 425 & $11500 \pm 90$ & $13355 \pm 97$ & $12689 \pm 96$ & $12249 \pm 164$ & 13000 \\
\hline AA-41763 & 442.5 & $11296 \pm 77$ & $13192 \pm 85$ & $12494 \pm 98$ & $11861 \pm 183$ & 12889 \\
\hline AA-41756 & 556.5 & $11471 \pm 62$ & $13331 \pm 67$ & $12657 \pm 67$ & $12202 \pm 128$ & 12990 \\
\hline AA-41757 & 741.5 & $12353 \pm 74$ & $14396 \pm 247$ & $13502 \pm 101$ & $13152 \pm 98$ & 13832 \\
\hline AAR-2603 & 826 & $12630 \pm 100$ & $14880 \pm 275$ & $13777 \pm 127$ & $13379 \pm 111$ & 14109 \\
\hline AAR-2604 & 974.5 & $12790 \pm 120$ & $15235 \pm 352$ & $13949 \pm 194$ & $13545 \pm 129$ & 14289 \\
\hline AA-41758 & 1008.5 & $12789 \pm 88$ & $15211 \pm 271$ & $13926 \pm 121$ & $13542 \pm 108$ & 14289 \\
\hline AA-41759 & 1345.5 & $12953 \pm 74$ & $15526 \pm 318$ & $14133 \pm 229$ & $13695 \pm 105$ & $14721+$ \\
\hline AAR-2605 & 1663 & $13810 \pm 170$ & $16925 \pm 198$ & $15890 \pm 416$ & $15028 \pm 457$ & 15995 \\
\hline AA-41760 & 1674 & $13020 \pm 110$ & $15721 \pm 366$ & $14356 \pm 280$ & $13765 \pm 137$ & $14739+$ \\
\hline AAR-2606 & 1815.5 & $14250 \pm 150$ & $17346 \pm 222$ & $16664 \pm 279$ & $15958 \pm 402$ & 16502 \\
\hline AA-41761 & 1821 & $13950 \pm 130$ & $17029 \pm 170$ & $16152 \pm 385$ & $15384 \pm 374$ & 16157 \\
\hline
\end{tabular}

Ages calibrated using OxCal v4.1, MARINE09. $\triangle R=0$, 300 and 700 (Bronk Ramsey, 2009; Reimer et al., 2009). *Ages from Wilson (2004) calibrated using Calib4_2 $\triangle R=0$, uncertainties not reported. †Average of three ages from shell fragments.

than the GS-1 value of 1000 years (Austin et al., 2011) and thus the $\delta^{18} \mathrm{O}_{\text {foram }}$ excursion is correlated with Gl-1d (Fig. 3).

Based upon this interpretation of the climate event-stratigraphy, the $\delta^{18} \mathrm{O}_{\text {foram }}$ stratigraphy can be tuned to the NGRIP $\delta^{18} \mathrm{O}_{\text {ice }}$ record using the GICC05 chronology (Rasmussen et al., 2006). For the rapid $\delta^{18} \mathrm{O}_{\text {foram }}$ changes at the onset and end of GS-1 and Gl-1d the tie-point was assigned to the midpoint of the transition. The Vedde Ash has been identified within MD95-2007 and more widely across the St Kilda basin (Austin et al., 1995, 2011; Peters et al., 2010). This tephra occurs at a core depth of $281 \mathrm{~cm}$ and has been assigned an age of 12171 b2k (Rasmussen et al., 2006). Table 2 summarizes the tie-points, their core depths and the ages assigned to them. During this interval the age uncertainty within the GICC05 time scale is 100-200 years (Rasmussen et al., 2006) but because we are comparing tuned records this has no influence on our conclusions. This age model follows the INTIMATE protocols (Lowe et al., 2008; Austin and Hibbert, 2012). It must be noted that this approach assumes synchroneity and therefore any information about time leads/lags is lost and conclusions based on the results must respect this limitation.

One complicating factor in the use of the tuning method to construct an age model for MD95-2007 is that there is no obvious structure to the local climate event-stratigraphy beyond the cold excursion Gl-1d. As a result age control in the lower section of the core is difficult; further dating may improve this but would be hampered by a general scarcity of suitable material in the lower core (W. E. N. Austin, pers. observ.). To anchor the base of the record it is therefore necessary to use the basal radiocarbon determination (13 $950 \pm$ $130{ }^{14} \mathrm{C}$ a BP) at a depth of $1821 \mathrm{~cm}$. This subsequently introduces an uncertainty related to the choice of $R_{(\mathrm{t})}$ used in the correction and then calibration of this age. The differences in the basal age calculated using the various corrections are significant and would affect any interpretations based on the timing of events in the lower $0.6 \mathrm{~m}$ of our record. Therefore, we avoid making interpretations based on data from the untuned section of the age model, which must be considered tentative. The effects of a variable correction are, however, restricted to this basal section of the core and are not a key factor when considering the tuned section to which this study relates.

\section{A new IRD record from MD95-2007}

$I D_{\text {flux }}$ is calculated from the IRD concentration and bulk mass accumulation rate (BMAR), such that:

$$
\mathrm{IRD}_{\text {flux }}=\mathrm{IRD}_{\text {conc }} * \mathrm{BMAR}
$$

The BMAR in turn is calculated using a linear sedimentation rate (LSR) derived from the age model and the dry bulk density $(\rho \mathrm{DB})$ of the sediment such that:

$$
\mathrm{BMAR}=\mathrm{LSR} * \rho \mathrm{DB}
$$

Calculation of the LSR involves linear interpolation between the tie points used in construction of the core's age model. $\rho \mathrm{DB}$ is calculated using the wet and dry mass of known volumes of sediment assuming sediment particle and pore water densities of 2650 and $1025 \mathrm{~kg} \mathrm{~m}^{-3}$ and pore water salinity of $35 \mathrm{~g} \mathrm{~kg}^{-1}$.

Lithic counts were carried out on the coarse $(>250 \mu \mathrm{m})$ fraction. Traditionally, grains coarser than $150 \mu \mathrm{m}$ are considered ice rafted (Hemming, 2004), but we use a coarser

\begin{tabular}{|c|c|c|c|}
\hline Tie point & Core depth $(\mathrm{cm})$ & Age assigned (b2k) & Reference \\
\hline End of GS-1 & 101 & 11703 & Lowe et al. (2008) \\
\hline Vedde Ash & 281 & 12171 & Rasmussen et al. (2006) \\
\hline Start of GS-1 & 521 & 12896 & Lowe et al. (2008) \\
\hline End of Gl-1d & 941 & 13954 & Lowe et al. (2008) \\
\hline Start of GI-1d & 1016 & 14075 & Lowe et al. (2008) \\
\hline
\end{tabular}

Table 2. Tie points used in construction of tuned age model. 


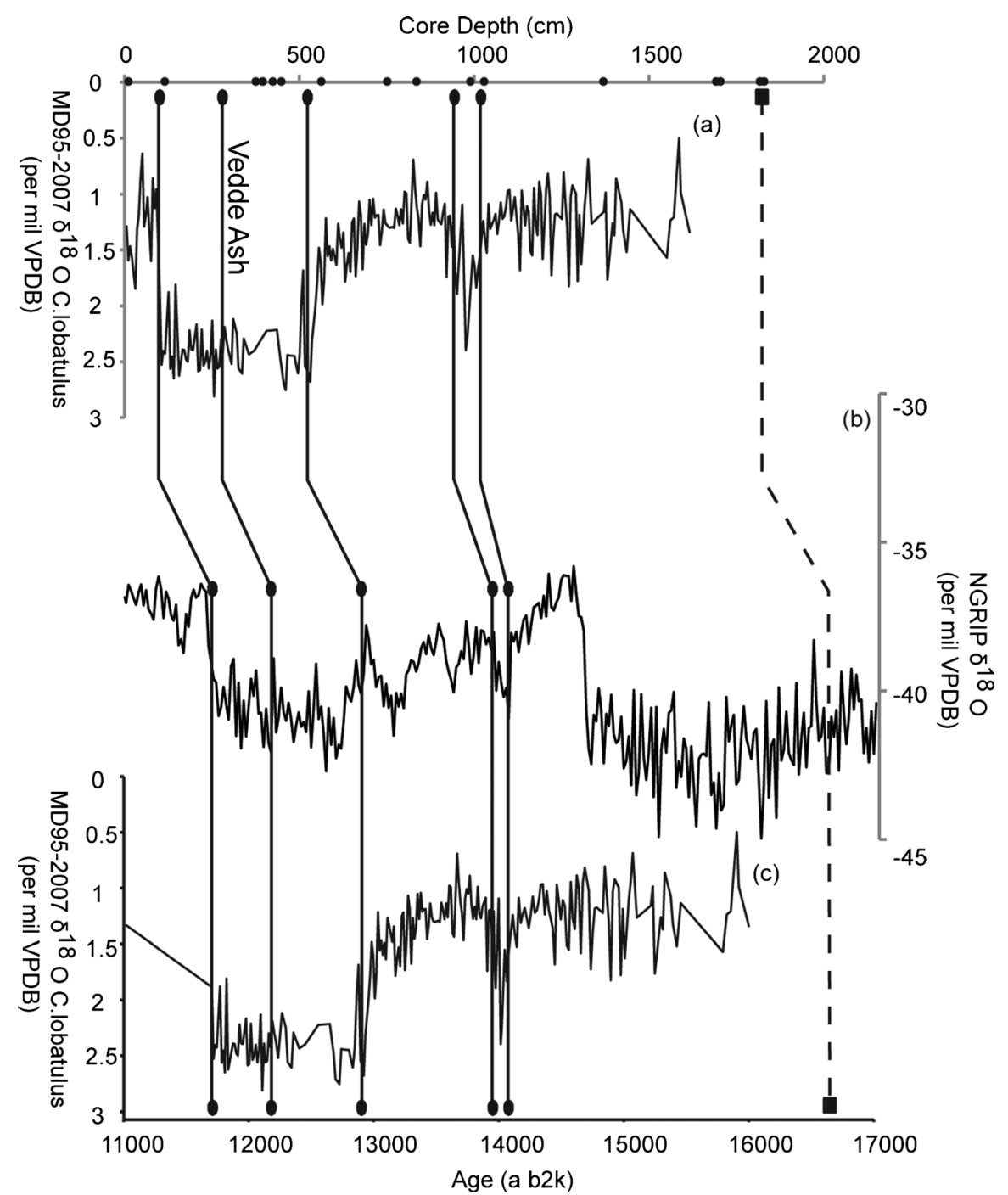

Figure 2. Final age model for MD95-2007. Tuning of the MD95-2007 benthic $\delta^{18} \mathrm{O}_{\text {foram }}$ record (Austin et al., 2011) to the NGRIP $\delta{ }^{18} \mathrm{O}$ record on the GICC05 time scale (Rasmussen et al., 2006). (a) MD95-2007 benthic $\delta^{18} \mathrm{O}$ against core depth; (b) NGRIP $\delta{ }^{18} \mathrm{O}$; (c) MD95-2007 benthic $\delta^{18} \mathrm{O}$ tuned using basal AMS ${ }^{14} \mathrm{C}$ date corrected for $\triangle R=300$. The solid lines show the tie points based on major climate transitions visible in both records; the dashed line indicates the basal radiocarbon age. Black dots on the top axis are available ${ }^{14} \mathrm{C}$ dates. The Vedde Ash isochron is labelled.

fraction because of the possibility that the shelf was a higher energy environment than the deep ocean, especially at times, such as the LGIT, when sea level was lower.

\section{Results}

The IRD flux record from core MD95-2007, plotted against the benthic $\delta^{18} \mathrm{O}_{\text {foram }}$ record (Fig. 4), shows three periods of increased IRD flux to the core site. The initial, and highest, period of increased flux occurs near the base of the core. $I D_{\text {flux }}$ during this time consistently exceeds 150000 grains $\mathrm{cm}^{-2} \mathrm{a}^{-1}$. This period corresponds to the missing part of the $\delta^{18} \mathrm{O}_{\text {foram }}$ stratigraphy such that age control is poor and resultant IRD flux uncertainty relatively high. Following this there is a period of near zero IRD flux which lasted until $\sim 14.1 \mathrm{ka}$. The subsequent peak in IRD corresponds to a significant $\delta^{18} \mathrm{O}_{\text {foram }}$ excursion correlated to Gl-1d (see above). After this brief (121 4 a; NGRIP/GICC05 time scale) period $I R D_{\text {flux }}$ returns to the very low background levels observed before Gl-1d. This low rate continues until a slow increase in IRD flux before the onset of GS-1 that is marked by a distinct increase in the $\mathrm{IRD}_{\text {flux }}$ to the core site. Following the end of GS-1, as defined in the $\delta^{18} \mathrm{O}_{\text {foram }}$ stratigraphy, $\mathrm{IRD}_{\text {flux }}$ rates are zero.

\section{Discussion}

The period of increased IRD flux centred on 14.1 ka coincides with a $\delta^{18} \mathrm{O}_{\text {foram }}$ excursion that has been correlated with the cold oscillation Gl-1d observed within the NGRIP $\delta^{18} \mathrm{O}_{\text {ice }}$ record (Rasmussen et al., 2006). Recent provenance work using $\mathrm{U}-\mathrm{Pb}$ dating of detrital minerals identifies a distinct distal component to the IRD found within MD95-2007, inferred to be sourced from north-eastern Canada, Baffin Island or East Greenland (Small et al., 2013). The provenance data presented by Small et al. (2013) do not preclude a contribution from local sources (i.e. the BIIS) and the abundance of coarse $(>250 \mu \mathrm{m})$ material is suggestive of a local source given the relationship between IRD grain size and transport distance (Andrews, 2000). However, it is doubtful that the BIIS had marine margins capable of supplying IRD to the offshore environment at this time (Bradwell et al., 2008; Ballantyne and Stone, 2012). It is possible that grain-specific provenance studies may be biased, particularly if the analysed grains come from a particular size fraction. Despite this potential limitation the distinct distal signal identified within the IRD provenance data provides clear evidence that IRD was transported some distance across the North Atlantic during the short cold oscillation GI-1d. 


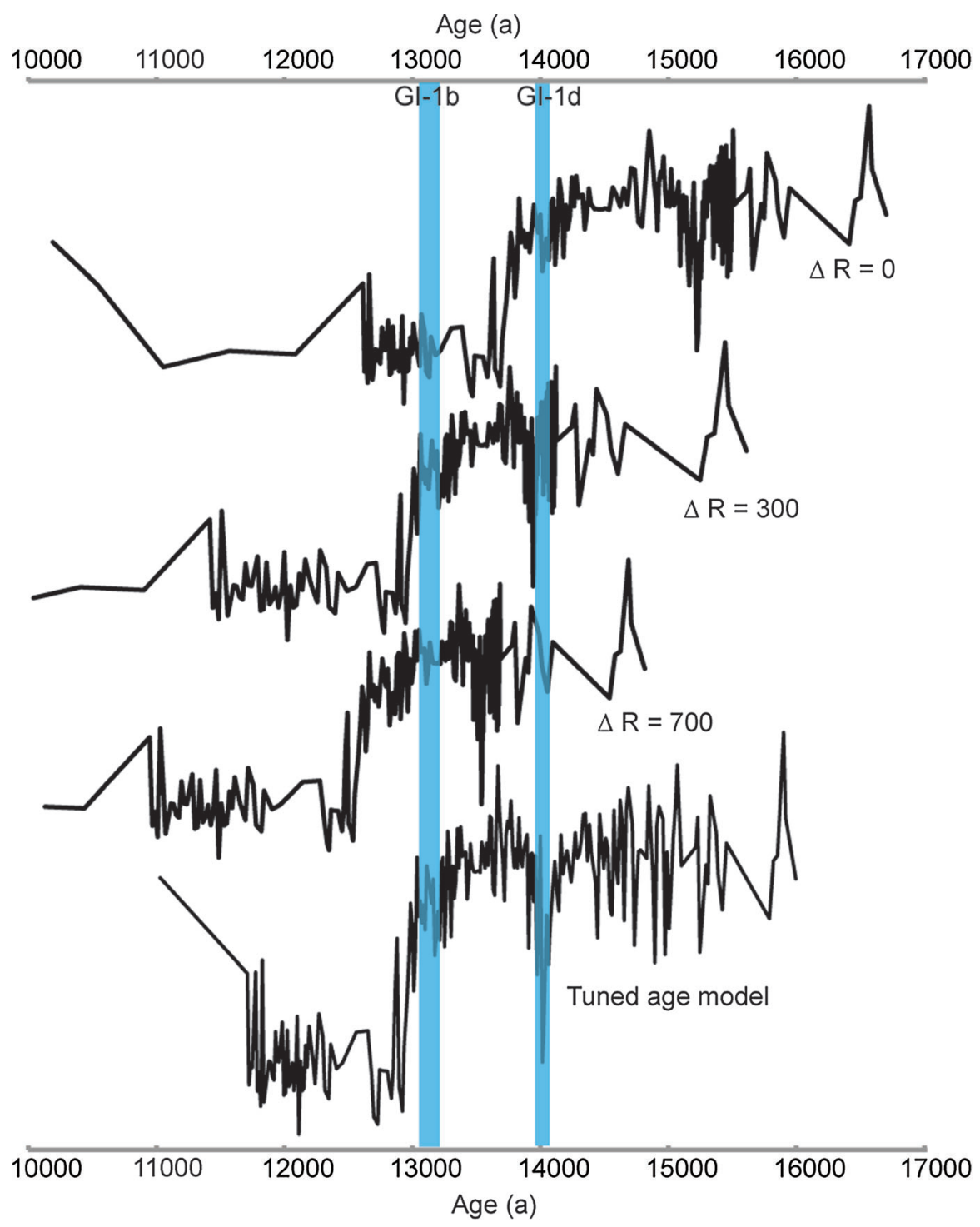

Figure 3. MD95-2007 $\delta^{18} \mathrm{O}_{\text {foram }}$ plotted using three 'preliminary' age models constrained by the available AMS ${ }^{14} \mathrm{C}$ dates (Table 1$)$ calibrated using OxCal v4.1 and MARINE09 (Bronk Ramsey, 2009; Reimer et al., 2009) and three different values for $\triangle R: 0,300$ and 700 . The tuned age model is shown for comparison.

The IRD flux and benthic $\delta^{18} \mathrm{O}_{\text {foram }}$ records from MD952007 are shown in comparison with proxy records from several other North Atlantic cores (DAPC-2, RAPid-15-4P, TTR-451; Fig. 5). The highlighted peak in IRD flux observed at $14.1 \mathrm{ka}$, which is co-registered with a $\delta^{18} \mathrm{O}_{\text {foram }}$ excursion within MD95-2007, also coincides with distinct increases in the IRD records in both DAPC-2 and RAPid-15-4P, indicating some common mechanism is responsible. However, it should be pointed out that the IRD record from RAPid-15-4P is concentration rather than flux, although the consistent pattern

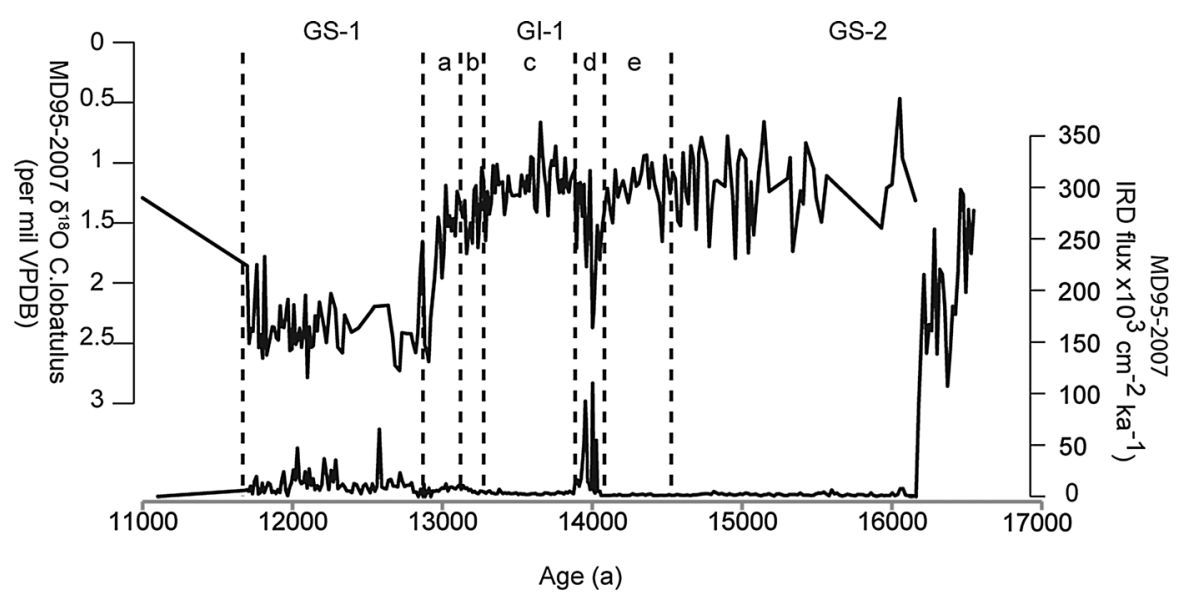

Figure 4. $M D 95-2007 \mid R D_{\text {flux }}$ record plotted against $\delta{ }^{18} \mathrm{O}_{\text {foram }}$ record using the tuned age model (Fig. 2). The stratigraphic divisions are as recommended by INTIMATE (Lowe et al., 2008). 


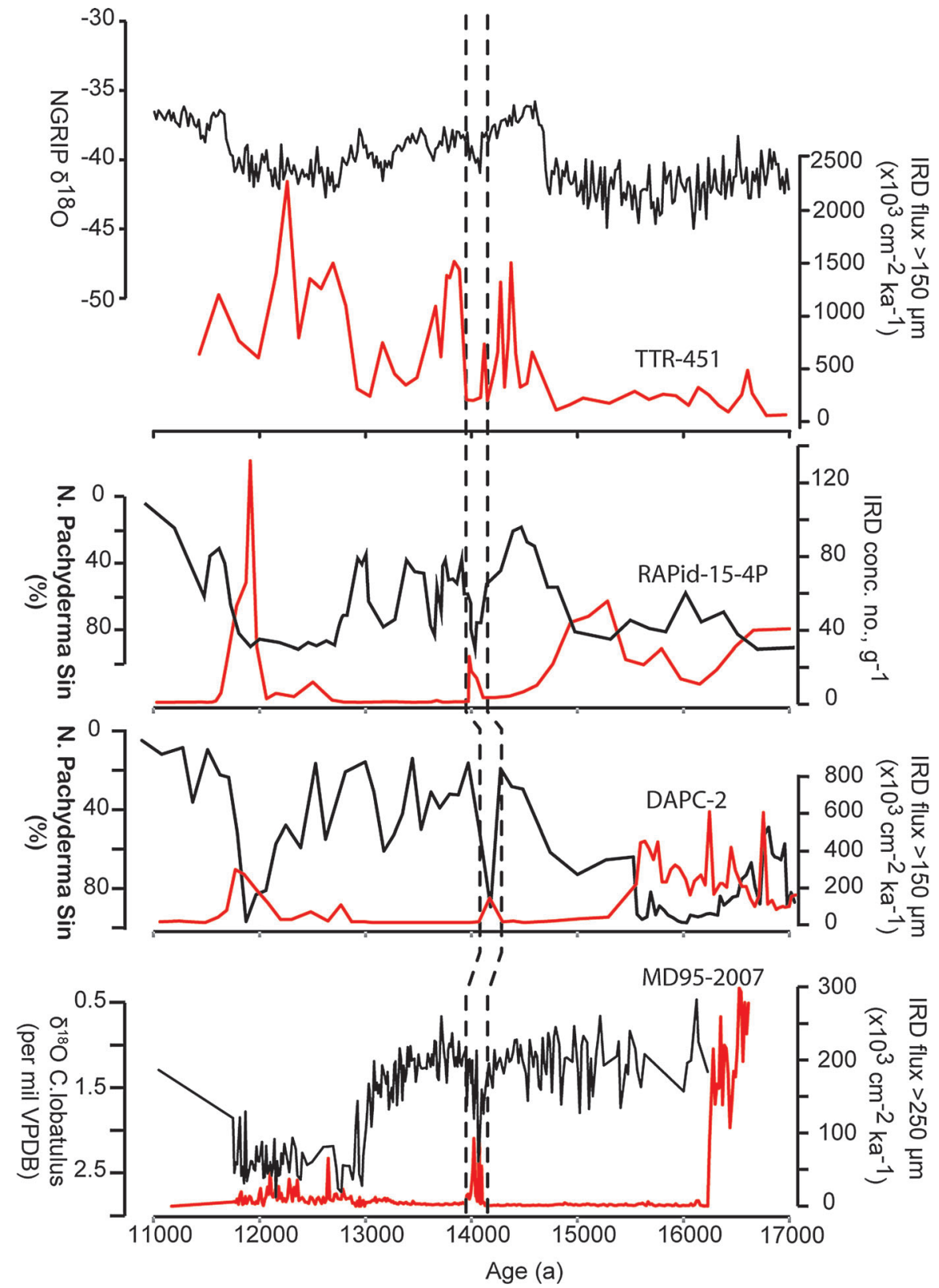

Figure 5. Composite stratigraphic plot of the IRD records discussed in the text plotted on their original time scales. The tuned proxies from MD95-2007 (this study; Austin et al., 2011), DAPC-2 (Knutz et al., 2007) and RAPid-15-4P (Thornalley et al., 2010) are shown alongside the IRD records. The NGRIP $\delta{ }^{18} \mathrm{O}$ record (Rasmussen et al., 2006) is shown alongside the IRD record from TTR-451 (Stanford et al., 2011). The age offset between DAPC-2 and the other records is the result of this record being tied to GISP2 $\delta^{18} \mathrm{O}$ (Grootes and Stuiver, 1997); the other records were tied to NGRIP $\delta^{18} \mathrm{O}$ on the GICC05 time scale (Rasmussen et al., 2006). This figure is available in colour online at wileyonlinelibrary.com.

between this and the flux records (MD-95-2007, DAPC-2) gives us confidence that it records the same event.

The IRD peak in RAPid-15-4P corresponds to the occurrence of an Icelandic tephra interpreted as being the Katla Ash. This tephra is also observed within the NGRIP record and can thus be assigned a precise age of 14020 b2k (Rasmussen et al., 2006; Thornalley et al., 2010). The age model of DAPC-2 was constructed by visual tuning of the $\mathrm{Nps} \%$ record with the GISP2 $\delta^{18} \mathrm{O}$ record (Knutz et al., 2007) which results in an age offset compared with the cores tuned to the NGRIP record (figure 10 in Rasmussen et al., 2006). The availability of AMS radiocarbon dates within this core is not sufficient to independently verify the tuning in this part of the stratigraphy. However, the stratigraphic position of the IRD peak suggests that it is correlative to GI- $1 \mathrm{~d}$ as it occurs at the same time as the earliest recorded peak in Nps\% during GI-1. This strongly indicates that the IRD peak represents the same event that is seen in MD95-2007 and RAPid-15-4P.
Considering the evidence for a distal contribution of IRD during Gl-1d (Small et al., 2013) it can be hypothesized that, if the overall flux of icebergs to the North Atlantic from these distal sources is the fundamental control on the occurrence of IRD within MD95-2007, then the MD95-2007 IRD flux record should reflect variations in this flux. A similar relationship should exist during Gl-1 for DAPC-2, which is inferred to have been predominantly supplied with BIIS -sourced IRD for most of its history (Knutz et al., 2007). Obtaining comparable provenance data from DAPC-2 would allow this assumption to be tested.

The IRD peaks during GI-1 seen within DAPC-2 and RAPid-15-4P occur during times of low SST indicated by relative high abundance of the planktonic foraminifera $\mathrm{N}$. pachyderma sinistral (Nps\%) (Knutz et al., 2007; Thornalley et al., 2010). The correlation between IRD peaks and peaks in $\mathrm{Nps} \%$ indicates that they occurred during times when the sites were located north of the Polar Front (Scourse 
et al., 2009). If the observed GI-1d IRD peaks simply reflected an increased flux of IRD to the North Atlantic, then it would be expected that they would record IRD at other times when it is recorded in ice-proximal core sites. Core TTR-451 from the Eirik Drift (Stanford et al., 2011) shows increased IRD flux throughout GI-1. It can be inferred from this that significant amounts of icebergs were calved from the Greenland Ice Sheet (GIS) at times when no IRD was reaching the distal core sites. Furthermore, models suggest that the GIS would have maintained calving margins for a large part of GI-1, providing a persistent possible source for icebergs (Simpson et al., 2009). This implies that some other control was acting to prevent deposition at the ice-distal sites at times of continuing iceberg flux to higher latitudes.

A series of rapid variations in SST are observed in the Nps $\%$ records from cores DAPC2 and RAPid-15-4P (Knutz et al., 2007; Thornalley et al., 2010). In each core one of these variations is correlated with Gl-1d and is coincident with the GI-1 IRD peak. Nps\% peaks indicating cooler periods of SST during Gl-1 are also seen in core MD95-2006, taken from the Barra Fan, $<100 \mathrm{~km}$ south-west of MD952007 (Wilson et al., 2002; Hibbert et al., 2010; Peters et al., 2010). It is reasonable to assume that one of the peaks corresponds to Gl-1d given the widespread and simultaneous nature of climate change in the North Atlantic at this time (Bjorck et al., 1996; Broecker, 2000; Rohling et al., 2003). An additional record from the Barra Fan based on the planktonic foraminiferal assemblages in core VE56/-10/36 also shows a variation in SST around the time of Gl-1d (Kroon et al., 1997). The occurrence of these brief periods of lower SST would favour the southerly penetration of icebergs calved from the surviving North Atlantic ice sheets because of the fundamental control SST has on the survival of icebergs in the ocean (Dowdeswell and Murray, 1990). Given the absence of IRD at times of higher SSTs when there was a continuing flux of icebergs from the same potential sources, it is likely that it is SST which was the fundamental control on IRD dispersal to the sub-polar North Atlantic during Gl-1. The occurrence of a peak in IRD flux associated with GI-1d is inferred to be the result of the attendant reduction in SSTs associated with this climatic oscillation.

SSTs in the North Atlantic depend strongly on AMOC, with a weaker AMOC associated with lower SSTs at higher latitudes (Schmittner et al., 2005; Barker et al., 2009). Rerouting events have been identified that correspond to the abrupt climate reversals of the last deglaciation (Clark et al., 2001) and one such release of freshwater is proposed as the cause of Gl-1d and its concomitant cooling that is seen across the North Atlantic (Rasmussen et al., 2006; Thornalley et al., 2010). This freshwater input probably caused an AMOC slowdown with an associated decrease in SSTs, visible in the palaeorecords and sufficient to allow icebergs (and IRD) to reach MD95-2007 and other ice-distal sites.

The LGIT was punctuated by periods of increased meltwater input from the decaying ice sheets (Fairbanks, 1989; Hanebuth et al., 2000; Bard et al., 2010). These meltwater pulses had various sources but their effects, in terms of both sea level rise and climate, were widespread (Stanford et al., 2006, 2010). The largest of the identified meltwater pulses is MWP-1a, whose initial contributor is thought to be the Antarctic Ice Sheet (AIS), where partial collapse released freshwater into the Southern Ocean (Clark et al., 2002). Resumption in North Atlantic deep water formation forced by a Southern injection of meltwater and resulting in warming in the Northern Hemisphere (Weaver et al., 2003) would explain the Bølling warming that marks the end of the Last Glacial Maximum and the start of Gl-1 (Lowe et al., 2008).
This warming would have favoured melting of the Northern Hemisphere ice sheets, which would have made a subsequent contribution to MWP-1a (Carlson et al., 2012), in turn diminishing the vigour of AMOC. This interaction produces a feedback between ice sheets and climate (Clark et al., 2001, 2009; McManus et al., 2004; Meissner and Clark, 2006; Thornalley et al., 2010; He et al., 2013). The evidence presented in this study demonstrates a rapid alteration to the North Atlantic's surface hydrography during the last deglaciation, in agreement with this proposed feedback mechanism.

\section{Conclusions and implications}

The co-registered, high-resolution $I R D_{\text {flux }}$ and $\delta{ }^{18} \mathrm{O}_{\text {foram }}$ records from MD95-2007 provide evidence of an IRD peak during Gl-1 that is coincident with a period of lower $\delta^{18} \mathrm{O}_{\text {foram }}$ values. The timing of this event is constrained using ${ }^{14} \mathrm{C}$ dates and tuning of the record to NGRIP and is correlated with the short-lived cooling episode Gl-1d (14 075-13 954 b2k). Given our knowledge of the distribution of the panNorth Atlantic ice sheets and IRD provenance fingerprinting using U-Pb dating of detrital minerals (Small et al., 2013) it has been established that the IRD peak in MD95-2007 reflects input of distally sourced material. The absence of IRD in southerly (ice-distal) cores at times when its flux at a northerly (ice proximal) core was continuing suggests that IRD flux to the wider North Atlantic from the surviving ice sheets is not the primary control. To explain this pattern of IRD occurrence it is necessary to invoke a hydrographic control that prevents IRD deposition at ice-distal sites except during a defined cold interval, namely lowered SST.

The release of freshwater into the North Atlantic is proposed as the driving mechanism of the short-lived and abrupt climate variations, such as Gl-1d. The effects of freshwater input to the North Atlantic are primarily manifested through a slowdown of AMOC that reduces SSTs. A reduction in SSTs favours the survival of icebergs and their wider dispersal. As such we suggest that it is by this mechanism that IRD was deposited within these sub-polar cores during Gl-1d. The widespread effects of meltwater input to the North Atlantic during the LGIT are clearly documented, but our evidence is some of the first that does not rely on planktonic foraminiferal $\delta^{18} \mathrm{O}$ alone.

Our conclusion that the GI-1 IRD peak within MD95-2007 contains distal material (Small et al., 2013) and that hydrographic conditions are important controls on sub-polar IRD dispersal has far-reaching implications. IRD has regularly been used to infer fine-scale behaviour of individual ice sheets. For example, IRD deposited during the last glacial cycle in the sub-polar North Atlantic records sub-Milankovitch (millennial)-scale climatic changes that have been linked to the abrupt calving dynamics of marine ice-sheet margins (eg Knutz et al., 2001; Scourse et al., 2009; Hibbert et al., 2010). By combining geographically distinct IRD records, information regarding IRD flux to the wider ocean and IRD provenance studies it is possible to demonstrate that hydrography may be an important additional control on IRD occurrence. Our results highlight, particularly at the millennial and sub-millennial scale, that IRD flux records may reflect a complex interplay between changes to oceanic conditions and ice sheet calving dynamics.

Acknowledgements. This work was undertaken while D. S. was in receipt of a SAGES PhD studentship at the University of St Andrews. We thank the captain and crew of the RV Marion Dufresne (MD 101) for core collection and L. Labeyrie, in particular. R. Søras and C. Murray provided technical assistance. Support for this research to 
WENA was provided from the NERC RAPID programme, NERC RCL, the Universities of St Andrews and Bergen and the WHOI-Mary Sears Fund. We thank two anonymous reviewers for constructive comments that have improved the manuscript.

Abbreviations. AMOC, Atlantic Meridional Overturning Circulation; AMS, accelerator mass spectrometry; BIIS, British-Irish Ice Sheet; BMAR, bulk mass accumulation rate; GIS, Greenland Ice Sheet; IRD, ice-rafted detritus; LGIT, Lastglacial-Interglacial Transition; LSR, linear sedimentation rate; SST, sea surface temperature.

\section{References}

Alley RB, Marotzke J, Nordhaus WD, et al. 2003. Abrupt climate change. Science 299: 2005-2010.

Andrews JT. 2000. Icebergs and iceberg rafted detritus (IRD) in the North Atlantic: facts and assumptions. Journal of Oceanography 13: 100-108.

Austin WEN. 1991. Late Quaternary benthonic foraminiferal startigraphy of the western UK continental shelf. PhD thesis, University of Wales.

Austin WEN, Bard E, Hunt JB, et al. 1995. The ${ }^{14} \mathrm{C}$ age of the Icelandic Vedde Ash: implications for Younger Dryas marine reservoir age corrections. Radiocarbon 37: 53-62

Austin WEN, Hibbert FD. 2012. Tracing time in the ocean: a brief review of chronological constraints (60-18 ka) on North Atlantic marine event-based stratigraphies. Quaternary Science Reviews 36: 28-37.

Austin WEN, Kroon D. 1996. Late glacial sedimentology, foraminifera and stable isotope stratigraphy of the Hebridean Continental Shelf, Northwest Scotland. Geological Society, London, Special Publications 111: 187-213.

Austin WEN, Kroon D. 2001. Deep sea ventilation of the northeastern Atlantic during the last 15,000 years. Global and Planetary Change 30: 13-31.

Austin WEN, Telford RJ, Ninnemann US, et al. 2011. North Atlantic reservoir ages linked to high Younger Dryas atmospheric radiocarbon concentrations. Global and Planetary Change 79: 226-233.

Ballantyne CKB, Stone JO. 2012. Did large ice caps persist on low ground in north-west Scotland during the Lateglacial Interstade. Journal of Quaternary Science 27: 297-306.

Bard E, Hamelin B, Delanghe-Sabatier D. 2010. Deglacial meltwater pulse $1 \mathrm{~B}$ and Younger Dryas sea levels revisited with boreholes at Tahiti. Science 327: 1235-1237.

Barker S, Diz P, Vautravers MJ, et al. 2009. Interhemispheric Atlantic seesaw response during the last deglaciation. Nature 457: 10971102.

Bjorck S, Kromer B, Johnsen S, et al. 1996. Synchronized terrestrialatmospheric deglacial records around the North Atlantic. Science 274: 1155-1160.

Bond G, Broecker WS, Johnsen S, et al. 1993. Correlations between climate records from North Atlantic sediments and Greenland ice. Nature 365: 143-147.

Bradwell T, Fabel D, Stoker M, et al. 2008. Ice caps existed throughout the Lateglacial Interstadial in northern Scotland. Journal of Quaternary Science 23: 401-407.

Broecker WS. 1994. Massive iceberg discharges as triggers for global climate change. Nature 372: 421-424.

Broecker WS. 2000. Abrupt climate change: causal constraints provided by the paleoclimate record. Earth-Science Reviews 51: 137-154.

Bronk Ramsey C. 2009. Bayesian analysis of radiocarbon dates. Radiocarbon 51: 337-360.

Carlson AE, Ullman DJ, Anslow FS, et al. 2012. Modeling the surface mass-balance response of the Laurentide Ice Sheet to Bølling warming and its contribution to meltwater pulse 1A. Earth and Planetary Science 315-316: 24-29.

Clark PU, Marshall SJ, Clarke GKC, et al. 2001. Freshwater forcing of abrupt climate change during the Last Glaciation. Science 293 : 283-287.

Clark PU, Pisias NG, Stocker TF, et al. 2002. The role of the thermohaline circulation in abrupt climate change. Nature $\mathbf{4 1 5}$ 863-869.
Clarke GKC, Bush ABG, Bush JWM. 2009. Freshwater discharge, sediment transport, and modeled climate impacts of the final drainage of glacial lake Agassiz. Journal of Climate 22: 21612180.

Davies HC, Dobson MR, Whittington RJ. 1984. A revised seismic stratigraphy for Quaternary deposits on the inner continental shelf west of Scotland between $55^{\circ} 30^{\prime} \mathrm{N}$ and $57^{\circ} 30^{\prime} \mathrm{N}$. Boreas 13: 4966.

Dowdeswell JA, Murray T. 1990. Modelling rates of sedimentation from icebergs. Geological Society, London, Special Publications 53: 121-137.

Elliot M, Labeyrie L, Dokken T, et al. 2001. Coherent patterns of ice-rafted debris deposits in the Nordic regions during the last glacial (10-60 ka). Earth and Planetary Sciences Letters 194: 151163.

Elliot M, Labeyrie L, Duplessy JC. 2002. Changes in North Atlantic deep-water formation associated with the Dansgaard-Oeschger temperature oscillations (60-10 ka). Quaternary Science Reviews 21: 1153-1165.

Fairbanks RG. 1989. A 175,000-year glacio-eustatic sea level record: influence of glacial melting rates on the Younger Dryas event and deep-ocean circulation. Nature 342: 637-642.

Grootes PM, Stuiver M. 1997. Oxygen 18/16 variability in Greenland snow and ice with 10- 3-to 105-year time resolution. Journal of Geophysical Research 102: 26455-26470.

Hanebuth T, Stattegger K, Grootes PM. 2000. Rapid flooding of the Sunda Shelf: a Late-Glacial sea-level record. Science 288: 10331035.

He F, Clark PU, Carlson AE, et al. 2013. Northern hemisphere forcing of southern hemisphere climate during the last deglaciation. Nature 494: 81-85.

Heinrich H. 1988. Origin and consequences of cyclic ice rafting in the Northeast Atlantic Ocean during the past 130,000 years. Quaternary Research 29: 142-152.

Hemming SR. 2004. Heinrich events: massive Late Pleistocene detritus layers of the North Atlantic and their global climate imprint. Reviews in Geophysics 42: RG1005.

Hendy IL, Cosma T. 2008. Vulnerability of the Cordilleran Ice Sheet to iceberg calving during late Quaternary rapid climate change events. Paleoceanography 23: PA2101.

Hibbert FD, Austin WEN, Leng MJ, et al. 2010. British Ice Sheet dynamics inferred from North Atlantic ice-rafted debris records spanning the last 175000 years. Journal of Quaternary Science 25: 461-482.

Knutz PC, Austin WEN, Jones EJW. 2001. Millennial-scale depositional cycles related to British Ice Sheet variability and North Atlantic paleocirculation since 45 kyr BP, Barra Fan, UK margin. Paleoceanography 16: 53-64.

Knutz PC, Zahn R, Hall IR. 2007. Centennial-scale variability of the British Ice Sheet: implications for climate forcing and Atlantic meridional overturning circulation during the last deglaciation. Paleoceanography 22: PA1207.

Kroon D, Austin WEN, Chapman MR, et al. 1997. Deglacial surface circulation changes in the Northeastern Atlantic: temperature and salinity records off NW Scotland on a century Scale. Paleoceanography 12: 755-763.

LeGrande AN, Schmidt GA, Shindell DT, et al. 2006. Consistent simulations of multiple proxy responses to an abrupt climate change event. Proceedings of the National Academy of Sciences of the United States of America 103: 837-842.

Liu Z, Otto-Bliesner BL, He F, et al. 2009. Transient simulation of last deglaciation with a new mechanism for Bølling-Allerød warming. Science 325: 310-314.

Lowe JJ, Rasmussen SO, Bjorck S, et al. 2008. Synchronisation of palaeoenvironmental events in the North Atlantic region during the Last Termination: a revised protocol recommended by the INTIMATE group. Quaternary Science Reviews 27: 6-17.

Marshall SJ, Koutnik MR. 2006. Ice sheet action versus reaction: distinguishing between Heinrich events and Dansgaard-Oeschger cycles in the North Atlantic. Paleoceanography 21: PA2021.

McCabe AM, Clark PU. 1998. Ice-sheet variability around the North Atlantic Ocean during the last deglaciation. Nature 392: 373377. 
McManus JF, Bond GC, Broecker WS, et al. 1994. High-resolution climate records from the North Atlantic during the last interglacial. Nature 371: 326-329.

McManus JF, Francois R, Gherardi JM, et al. 2004. Collapse and rapid resumption of Atlantic meridional circulation linked to deglacial climate changes. Nature 428: 834-837.

Meissner KJ, Clark PU. 2006. Impact of floods versus routing events on the thermohaline circulation. Geophysical Research Letters 33: L15704.

Naafs BDA, Hefter J, Ferretti P, et al. 2011. Sea surface temperatures did not control the first occurrence of Hudson Strait Heinrich Events during MIS 16. Paleoceanography 26: PA4201.

Peacock JD, Austin WEN, Selby I, et al. 1992. Late Devensian and Flandrian palaeoenvironmental changes on the Scottish continental shelf west of the Outer Hebrides. Journal of Quaternary Science 7: $145-161$.

Peck VL, Hall IR, Zahn R, et al. 2007. The relationship of Heinrich events and their European precursors over the past 60 ka BP: a multi-proxy ice-rafted debris provenance study in the North East Atlantic. Quaternary Science Reviews 26: 862-875.

Peters C, Austin WEN, Walden J, et al. 2010. Magnetic characterisation and correlation of a Younger Dryas tephra in North Atlantic marine sediments. Journal of Quaternary Science 25: 339347.

Rahmstorf S. 2002. Ocean circulation and climate during the past 120,000 years. Nature 419: 207-214.

Rasmussen SO, Andersen KK, Svensson AM, et al. 2006. A new Greenland ice core chronology for the last glacial termination. Journal of Geophysical Research 111: D06102.

Reimer PJ, Baillie MGL, Bard E, et al. 2009. INTCAL09 and MARINE09 radiocarbon age calibration curves, 0-50,000 years cal BP. Radiocarbon 51: 1111-1150.

Rohling ER, Mayewski PM, Challenor PC. 2003. On the timing and mechanism of millennial-scale climate variability during the last glacial cycle. Climate Dynamics 20: 257-267.

Ruddiman WF. 1977. Late Quaternary deposition of ice-rafted sand in the subpolar North Atlantic (lat 40 to 65 N). Geological Society of America Bulletin 88: 1813-1827.

Ruddiman WF, McIntyre A. 1981. The North Atlantic Ocean during the last deglaciation. Palaeogeography, Palaeoclimatology, Palaeoecology 35: 145-214.

Schmittner A, Latif M, Schneider B. 2005. Model projections of the North Atlantic thermohaline circulation for the 21st century assessed by observations. Geophysical Research Letters 32: L23710.

Scourse JD, Haapaniemi Al, Colmenero-Hidalgo E, et al. 2009. Growth, dynamics and deglaciation of the last British-Irish ice sheet: the deep-sea ice-rafted detritus record. Quaternary Science Reviews 28: 3066-3084.
Severinghaus JP, Brook EJ. 1999. Abrupt climate change at the end of the Last Glacial period inferred from trapped air in polar ice. Science 286: 930-934.

Simpson MJR, Milne GA, Huybrechts P, et al. 2009. Calibrating a glaciological model of the Greenland ice sheet from the Last Glacial Maximum to present-day using field observations of relative sea level and ice extent. Quaternary Science Reviews 28: 1631-1657.

Small D, Parrish RR, Austin WEN, et al. 2013. Provenance of North Atlantic ice-rafted debris during the last deglaciation-A new application of U-Pb rutile and zircon geochronology. Geology 45: 155-158.

Stanford JD, Hemingway R, Rohling EJ, et al. 2010. Sea-level probability for the last deglaciation: a statistical analysis of far-field records. Global and Planetary Change 79: 193-203.

Stanford JD, Rohling EJ, Bacon S, et al. 2011. A new concept for the paleoceanographic evolution of Heinrich event 1 in the North Atlantic. Quaternary Science Reviews 30: 1047-1066.

Stanford JD, Rohling EJ, Hunter SE, et al. 2006. Timing of meltwater pulse 1a and climate responses to meltwater injections. Paleoceanography 21: PA4103.

Steffensen JP, Andersen KK, Bigler M, et al. 2008. High-Resolution Greenland ice core data show abrupt climate change happens in few years. Science 321: 680-684.

Stoker M, Hitchen K, Graham CC. 1993. United Kingdom Offshore Report: the Geology of the Hebrides and West Shetland Shelves, and Adjacent Deep-Water Areas. HMSO for the British Geological Survey, London.

Stuiver M, Reimer PJ. 1993. Extended ${ }^{14} \mathrm{C}$ database and revised CALIB $3.0{ }^{14} \mathrm{C}$ age calibration program. Radiocarbon 35: 215-230.

Stuiver M, Reimer PJ, Bard E, et al. 1998. INTCAL98 radiocarbon age calibration, 24,000-0. cal BP. Radiocarbon 40: 1041-1083.

Thornalley DJR, McCave IN, Elderfield H. 2010. Freshwater input and abrupt deglacial climate change in the North Atlantic. Paleoceanography 25: PA1201.

Vidal L, Labeyrie L, Cortijo E, et al. 1997. Evidence for changes in the North Atlantic Deep Water linked to meltwater surges during the Heinrich events. Earth and Planetary Sciences Letters 146: 13-27.

Waelbroeck C, Duplessy JC, Michel E, et al. 2001. The timing of the last deglaciation in North Atlantic climate records. Nature 412: 724-727.

Weaver AJ, Saenko OA, Clark PU, et al. 2003. Meltwater pulse 1A from Antarctica as a trigger of the Bølling-Allerød warm interval. Science 299: 1709-1713.

Wilson LJ. 2004. Late Quaternary stratigraphies from the Hebridean Continental Shelf and Margin, North West Scotland, United Kingdom. PhD thesis, University of St Andrews.

Wilson LJ, Austin WEN, Jansen E. 2002. The last British Ice Sheet: growth, maximum extent and deglaciation. Polar Research 21: 243-250. 